\title{
SINTESIS DAN UJI BIOAKTIVITAS SENYAWA ANALOG UK-3A \\ 6-HIDROKSI-N-OKTILNIKOTINAMIDA
}

\author{
${ }^{1}$ Dadan Ridwanuloh \\ ${ }^{2}$ Herry Cahyana \\ ${ }^{3}$ Muhammad Hanafi
}

\begin{abstract}
${ }^{1}$ Jurusan Farmasi Fakultas Tekhnik dan Ilmu Komputer Universitas Buana Perjuangan Karawang (dadan.ridwanuloh@ubpkarawang.ac.id)

${ }^{2}$ Departemen Kimia, FMIPA UI, Kampus UI Depok 16424 ( herrykim@makara.cso.ui.ac.id )

${ }^{3}$ Pusat Penelitian Kimia - Lembaga Ilmi Pengetahuan Indonesia ( muhammad.hanafi@lipi.go.id )
\end{abstract}

UNIVERSITAS BUANA PERJUANGAN, KARAWANG

Jl. HS Ronggowaluyo, Telukjambe Timur, Karawang

\begin{abstract}
Abstrak
Senyawa UK-3A telah diketahui merupakan senyawa aktif untuk anti kanker dan anti jamur. Senyawa UK-3A telah diisolasi sebagai komponen minor dari miselium Streptomyces sp. 512-02 dan mempunyai gugus aktif hidroksil, amida, dan dilakton cincin sembilan yang terbukti aktif menghambat pertumbuhan bakteri dan sel kanker. Untuk mensintesis senyawa tersebut membutuhkan proses sintesis yang rumit dan waktu yang cukup lama. Pada Penelitian ini disintesis senyawa analog UK-3A yaitu 6-hidroksi-N-oktilnikotinamida berdasarkan modifikasi gugus aktif senyawa UK-3A. Modifikasi gugus aktif dalam senyawa UK-3A dimungkinkan untuk mendapatkan senyawa analog yang mempunyai bioaktivitas yang sama atau lebih aktif dari senyawa UK-3A induk dan dengn reaksi yang sederhana. Kedua senyawa hasil sintesis tersebut diidentifikasi menggunakan KLT, 1H-NMR, dan 13CNMR. Hasil uji bioaktivitas metode brine shrimp lethality test (BSLT) terhadap kedua senyawa diperoleh nilai LC50 sebesar $41,14 \mu \mathrm{g} / \mathrm{mL}$.
\end{abstract}




\begin{abstract}
Compound UK-3A is a known active compounds for anti-cancer and anti-fungal. UK-3A compound was isolated as a minor component of the mycelium of Streptomyces sp . 512-02 and have active groups hydroxyl, amide, and dilakton nine rings were shown to actively inhibit the growth of bacteria and cancer cells . To synthesize these compounds require complicated synthesis process and longer periods of time. In this study synthesized compound UK-3A analogue that is 6-hydroxy-N-octylnicotinamide modifications based active group of compounds UK-3A . Modification of active groups in the compound UK-3A analogue is possible to obtain compounds that have the same bioactivity or more active than the parent compound UK-3A and simple with less reaction. Both compounds synthesized were identified by TLC, FTIR, 1H-NMR, and 13C-NMR. Test results of brine shrimp lethality bioactivity test method (BSLT) of the two compounds obtained LC50 values of $41,14 \mathrm{mg} / \mathrm{mL}$.
\end{abstract}

Keywords: UK-3A, anti-cancer, Streptomyces sp.

\title{
1. PENDAHULUAN
}

Salah satu yang menjadi kajian bagi para peneliti di bidang kimia farmasi adalah eksplorasi suatu senyawa kimia aktif, baik dari alam maupun hasil sintesis. Senyawa aktif ini digunakan untuk mengatasi penyakit-penyakit yang biasa terjangkit pada manusia yang belum didapatkan obat yang tepat untuk mengatasinya. Diantara penyakit yang saat ini menjadi kajian populer adalah penyakait kanker. Selain Penyakit kanker merupakan salah satu penyakit dengan jumlah korban jiwa yang sangat besar di dunia, juga penyebarannyapun merata di seluruh negara, baik negara berkembang maupun negara maju.

Pada tahun 1995 Ueki telah berhasil mengisolasi dan mengelusidasi struktur senyawa UK-2A dan UK-3A dari miselium Streptomyces sp. 517-02 (Hanafi et.al.1996). dari hasi uji bioaktivitasnya UK-3A diketahui memiliki aktifitas yang cukup baik sabegai antikanker, antifungal dan antijamur. Akan tetapi, selain karena senyawa UK-3A merupakan komponen minor juga randemen isolatnya yang kecil serta rute atau tahapan isolasinya yang panjang dan tidak ekonomis. Oleh karena itu, berkembang riset yang mensintesis senyawa analog UK-3A dengan cara memodifikasi struktur dilaktonnya. 


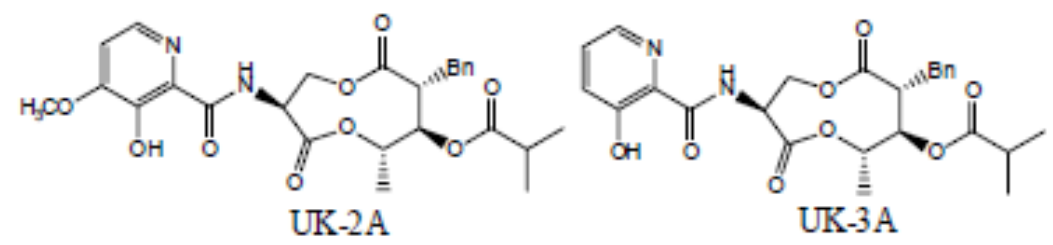

Gambar 1. Struktur molekul senyawa UK-2A (Hanafi, 1997).

Tabel 1. Hasil Uji Hambatan Pertumbuhan Sel Kanker Senyawa UK-2A, UK-3A dan Antimicyn A3 $\left(\mathrm{IC}_{50} \mu \mathrm{g} / \mathrm{mL}\right)$ (Hanafi, 1995)

\begin{tabular}{|l|c|c|c|}
\hline Sel Kanker & $\begin{array}{c}\text { Senyawa } \\
\text { UK-2A }\end{array}$ & $\begin{array}{c}\text { Senyawa } \\
\text { UK-3A }\end{array}$ & $\begin{array}{c}\text { Antimycin } \\
\mathbf{A 3}\end{array}$ \\
\hline P-388 & 100 & 38 & 0,015 \\
\hline B-16 & 100 & 18 & 0,02 \\
\hline KB & 17 & 20 & 0,063 \\
\hline COLO-201 & 35 & 45 & 0,018 \\
\hline 3T3 & 100 & 100 & 15 \\
\hline
\end{tabular}

Pada penelitian ini dilakukan sintesis dan uji bioaktivitas senyawa analog UK-3A dengan struktur yang lebih sederhana yaitu 6-hidroksi-N-oktilnikotinamida. Dengan struktur dan tahapan reaksi yang lebih sederhana, tetapi memiliki aktivitas yang sama dengan UK-3A bahkan bias lebih baik lagi.

\section{METODE PENELITIAN}

\section{Bahana}

Bahan-bahan yang akan digunakan antara lain asam 3-hidroksi pikolinat (Aldrich 15,230-7 p.a), oktil amin (p.a), disikloheksilkarbodimida (DCC, sigma D3128 p.a), dimetil amino piridin (DMAP, sigma D5640 p.a), pelarut organik (metanol, hexan, etil asetat), aquades, air laut, dimetil sulfoksida (DMSO), kertas saring, silika gel, dan plat kromatografi lapis tipis (KLT).

\section{Alat}

Peralatan yang digunakan dalam penelitian ini adalah kromatografi kolom, labu distilasi, hot plate, rotary evaporator, penangas air, lampu UV, Spektroskopi IR (FT-IR) dan spektrometer ${ }^{1} \mathrm{H}-\mathrm{NMR}$ dan ${ }^{13} \mathrm{C}-\mathrm{NMR}$, serta peralatan gelas kimia lainnya. 


\section{Sintesis 6-hidroksi-N-oktilnikotinamida}

Senyawa 6-hidroksi- $N$-oktilnikotinamida disintesis dengan menyediakan labu dasar bulat, kemudian diisi dengan $1 \mathrm{mmol}$ asam 3-hidroksipikolinik, 1,2 mmol oktil amin, $1 \mathrm{mmol}$ aktivator DCC, dan 0,1 mmol DMAP. Ke dalam labu ditambahkan $5 \mathrm{ml}$ pelarut kloroform. Kemudian reaksi dilakukan selama 24 jam dalam suhu kamar. Setelah reaksi berlangsung, larutan diperiksa secara kualitatif menggunakan kromatografi lempeng tipis dengan eluen nhexan: etil asetat 3:4 untuk mengetahui apakah rekasi sudah terbentuk atau belum.

\section{Uji bioaktivitas}

Brine shrimp lethality test (BSLT) merupakan uji toksisitas pendahuluan yang paling banyak digunakan terhadap suatu senyawa bioaktif. Keuntungan metode BSLT ini karena murah, mudah diperoleh, dapat bertahan hidup beberapa tahun dalam keadaan kering, mudah dan cepat dalam pelaksanaannya, serta hanya menggunakan peralatan yang cukup sederhana.

Larva A. salina diperoleh dengan cara menetaskan telurnya dalam air laut atau air laut buatan selama 48 jam (Meyer, 1992) dengan suhu penetasan antara 20-35 ${ }^{\circ} \mathrm{C}$. Pada uji toksisitas digunakan larva A. salina berumur 24 jam sebanyak 10-15 ekor yang dimasukkan ke dalam vial berisi sample dengan beberapa konsentrasi berbeda, dan dibiarkan pada tempat dengan udara dan sinar yang cukup. Persentase kematian larva A. salina dihitung setelah 24 jam pemberian terhitung sejak larva dimasukkan ke dalam vial berisi sample uji, untuk kemudian dihitung nilai $\mathrm{LC}_{50}$-nya (konsentrasi senyawa uji dalam ppm yang dapat menyebabkan kematian sebanyak 50\% larva A. salina di bawah kondisi yang telah ditetapkan/sesuai (Rosalina, 1996).

\section{HASIL DAN PEMBAHASAN}

\section{Sintesis 6-hidroksi-N-oktilnikotinamida}

Dari hasil reaksi asam 6-hidroksi- $N$-nikotinat dengan oktil amin selama 24 jam setelah diperiksa dengan KLT menggunakan eluen n-hexan : etil asetat (3:4) sebagai fasa diam diperoleh 4 spot.

Karena spot 4 adalah spot yang lebih dominan dibandingkan dengan spot lainya yang berbeda dengan spot bahan bakunya, spot inilah yang terlebih dahulu diisolasi. Dari hasil analisis, spot 4 dengan $\mathrm{Rf}=0,725$ diduga sebagai senyawa target yaitu senyawa 6-hidroksi- $\mathrm{N}$ oktilnikotinamida hal ini disimpulkan setalah hasil karakterisasi.

Spot 1dengan $\mathrm{Rf}=0$ merupakan spot bahan baku yang masih tersisa. Hal ini ditunjukan dengan posisi spot yang sama dengan bahan baku yaitu asam 6-hidroksi- $N$-nikotinat. Adanya 
spot 1 ini juga menyatakan bahwa reaksi belum sempurna. Sedangkan spot 2 dan3 dengan $\mathrm{Rf}=0,45$ dan $\mathrm{Rf}=0,425$ merupakan produk samping reaksi. Produk samping reaksi dapat terjadi karena adanya reaksi yang tidak spesifik, sehingga terjadi reaksi pada gugus aktif lain yang tidak diinginkan.

Reaksi sintesis 6-hidroksi- $N$-oktilnikitinamida ini merupakan reaksi amidasi yang diajukan mengikuti mekanisme seperti pada gambar berikut:

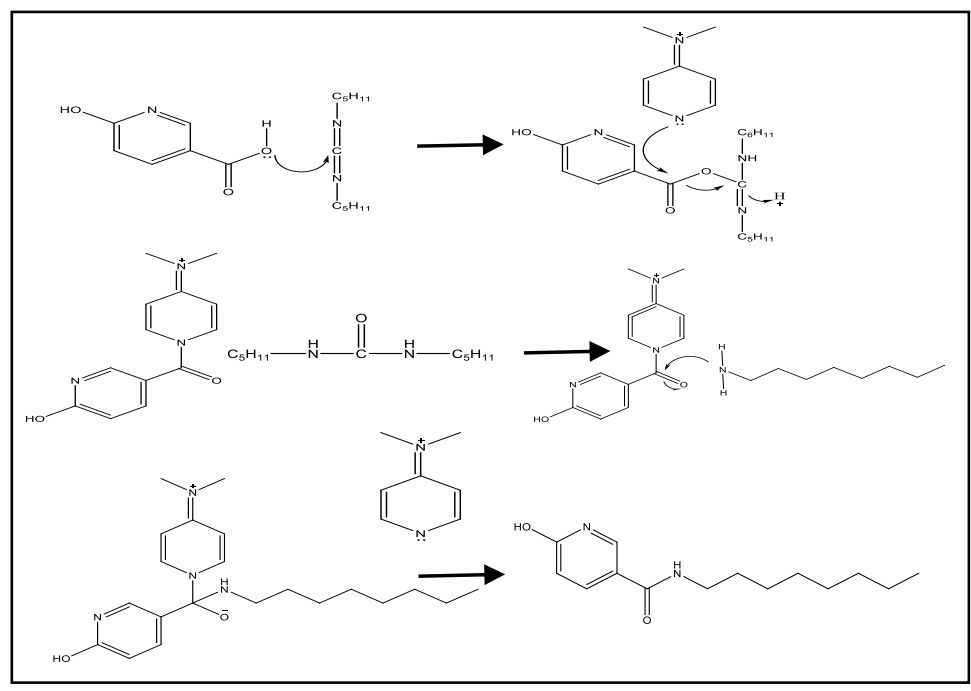

Gambar 2. Usulan Mekanisme Reaksi 6-hidroksi-N-oktilnikotinamida

\section{Karakterisasi}

\section{Analisis FT-IR}

Analisis sintesis senyawa 6-hidroksi- $N$-oktilnikotinamida menggunakan FT-IR. Dibuktikan bahwa sintesis senyawa analog UK-3A 6-hidroksi- $N$-oktilnikotinamida dan 3hidroksi-N-oktilpikolinamida sudah terbentuk. Hal ini ditunjukkan dengan adanya munculnya beberapa pita serapan yang menandakan gugus fungsi-gugus fungsi dari senyawa hasil reaksi.

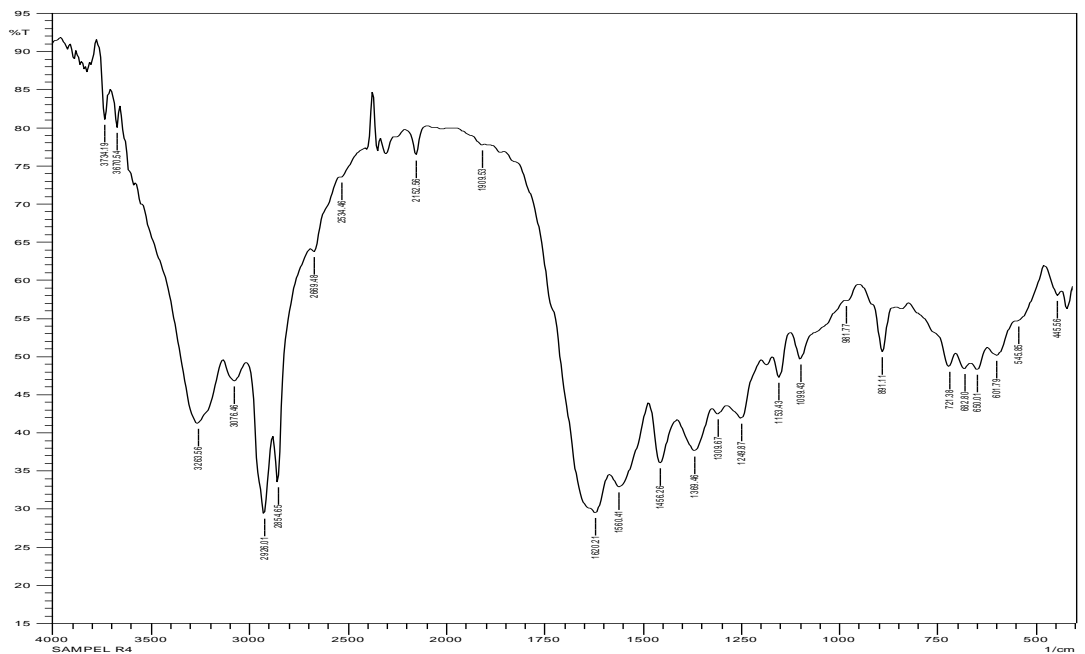

Gambar 4. Spektrum IR 6-hidroksi- $N$-oktilnikotinamida 
Pada sintesis 6-hidroksi- $N$-oktilnikotinamida, menunjukan adanya pita serapan pada $1620 \mathrm{~cm}^{-1}$ merupakan vibrasi ulur karbonil $(\mathrm{C}=\mathrm{O})$ dari amida. Serapan tunggal pada $3264 \mathrm{~cm}^{-}$ 1 merupakan vibrasi ulur $\mathrm{NH}$ dari amida sekunder. Adanya gugus $\mathrm{C}-\mathrm{H}$ alifatik juga ditunjukkan pada 2926-2855 $\mathrm{cm}^{-1}$. Informasi adanya $(\mathrm{C}=\mathrm{C})$ aromatis ditunjukkan dengan pita serapan pada $3077 \mathrm{~cm}^{-1}$.

\section{Analisis NMR}

Pembentukan amida pada hasil reaksi sintesis senyawa 6-hidroksi-N-nikotilamida ditunjukkan oleh adanya pergeseran kimia pada spektrum H-NMR yaitu pada pada pergeseran $\delta 8,22$ (d, CONH ) yang menunjukan proton pada gugus amida. Gugus aromatik pada cincin nikotinik ditunjukkan pada sinyal $\delta 7,68 ; 6,49 ;$ dan 5, 78 .

Spektrum C-NMR yang mendukung data terbentuknya gugus amida pada produk senyawa 6-hidroksi-N-oktilnikotinamida antara lain sinyal pada pergeseran kimia $\delta$ 164,9 ppm yang merupakan pergeseran kimia untuk karbon CONH. Sedangkan gugus aromatis pada cincin nikotiniknya terdapat pada pergeseran $\delta 106-149 \mathrm{ppm}$.

Adanya gugus oktil ditunjukkan dengan adanya puncak pada $\delta 0,88 \mathrm{ppm}\left(\mathrm{t}, 3 \mathrm{H},-\mathrm{CH}_{3}\right)$ yang menunjukkan adanya pergeseran kimia dari 3 buah proton gugus metil yang bertetangga dengan gugus metilen $\left(-\mathrm{CH}_{2}\right)$ pada posisi $\mathrm{C} 8$ ', sedangkan puncak pada $\delta 1,58$ (abroad, 10H, ($\left.\mathrm{CH}_{2}\right)_{5}$ ) menunjukkan adanya pergeseran kimia dari 10 buah proton yang berasal dari 5 buah gugus metilen ( $\mathrm{C}=3^{\prime}, 4^{\prime}, 5^{\prime}, 6^{\prime}$ dan 7'). Puncak pada $\delta$ 2,9 ppm (multiplet, $2 \mathrm{H},-\mathrm{CH}_{2}-$ ) merupakan puncak dari gugus metilen pada posisi C-2' yang bertetangga dengan 2 buah gugus metilen lainnya, sedangkan puncak pada $\delta 3,41 \mathrm{ppm}\left(\mathrm{t}, 2 \mathrm{H},-\mathrm{CH}_{2}\right)$ menunjukkan adanya gugus metilen (C-1') yang downfield karena berikatan langsung dengan gugus elektronegatif yaitu oksigen.

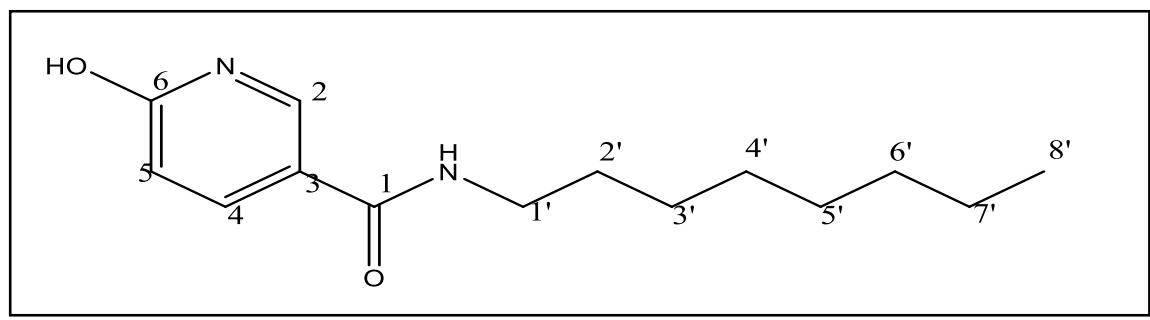

Gambar 6. Struktur 6-hidroksi-N-oktilnikotinamida 


\section{Uji Bioaktivitas}

\section{Uji Toksisitas dengan Metode Brine Shrimp Lethality Test ( BSLT)}

Uji aktivitas senyawa analog UK-3A, yaitu senyawa analog UK-3A yaitu 6-hidroksi-Noktilnikotinamida dan 3-hidroksi-N-oktilpikolinamida diawali dengan uji pendahuluan untuk mengetahui efek toksisitas $\left(\mathrm{LC}_{50}\right.$ ) senyawa melalui metode brine shrimp lethality test (BSLT). Uji BSLT dilakukan terhadap senyawa analog UK-3A yaitu 6-hidroksi-N-oktilnikotinamida dan 3-hidroksi- $N$-oktilpikolinamida menggunakan konsentrasi 10, 100, 500 dan 1000 ppm dalam media air laut dan dilakukan dengan 3 kali ulangan (triplo) dan menggunakan larva udang Artemia salina Leach. Masing-masing sebanyak 30 ekor/konsentrasi. Proses penetasan telur Artemia salina Leach. sampai dengan menjadi larva membutuhkan waktu 48 jam, dan mulai dari penambahan sampel uji terhadap larva udang sampai dengan proses perhitungan membutuhkan waktu 24 jam. Jumlah larva udang yang mati dan hidup dihitung, untuk kemudian ditentukan persentase kematian dengan cara membagi larva udang yang mati dengan jumlah larva udang hidup dikurangi kontrol. Nilai $\mathrm{LC}_{50}$ diperoleh melalui analisis regresi linear. Rata-rata hasil uji toksisitas senyawa senyawa analog UK-3A yaitu 6-hidroksi$\mathrm{N}$-oktilnikotinamida dan 3-hidroksi- $N$-oktilpikolinamida pada berbagai konsentrasi dapat dilihat pada Lampiran.

Dari hasil tersebut diketahui bahwa kedua senyawa senyawa analog UK-3A yaitu 6hidroksi-N-oktilnikotinamida mempunyai tingkat toksisitas yang cukup tinggi yaitu 41,14 ppm, jika digunakan dasar yang diambil dari Meyer (1992) yang menyatakan bahwa suatu senyawa mempunyai efek toksisitas yang signifikan (tinggi) jika mempunyai nilai $\mathrm{LC}_{50} \leq 50$ ppm. Uji pendahuluan ini dengan menggunakan BSLT membuktikan bahwa senyawa hasil reaksi senyawa analog UK-3A, yaitu senyawa analog UK-3A yaitu 6-hidroksi-Noktilnikotinamida memiliki toksisitas yang cukup signifikan.

\section{KESIMPULAN}

Hasil identifikasi lebih lanjut menggunakan KLT, FT-IR, ${ }^{1} \mathrm{H}-\mathrm{NMR}$ dan ${ }^{13} \mathrm{C}-\mathrm{NMR}$ membuktikan bahwa senyawa analog UK-3A yaitu 6-hidroksi-N-oktilnikotinamida berhasil disintesis. Sedangkan hasil uji toksisitas pendahuluan disimpulkan bahwa senyawa 6hidroksi-N-oktilnikotinamida dan dan berpotensi sebagai antikanker hal ini ditunjukkan dengan adanya aktivitas yang cukup signifikan dengan nilai LC $_{50}$ masing-masing sebesar $41,14 \mathrm{ppm}$. 


\section{DAFTAR PUSTAKA}

1)Ardinata, E., 2007. “Sintesis Senyawa Analog UK-3A : 3-Hidroksipikolinil-dioktil Glutamat dan 2-Hidroksinikotinildioktil Glutamat dan Uji Sitotoksisitas terhadap Sel Kanker Murine Leukemia P-388”, Tesis, Magister Sains Ilmu Kimia, Program Pascasarjana U.I, Depok.

2)Budi, G.S., 2006. “Identifikasi Senyawa Bioaktif Ekstrak Kulit Batang Tanjang (Bruguiera gymnorhiza) dalam Etanol dan Uji Sitotoksisitasnya terhadap Sel HeLa", Skripsi, Program Sarjana, MIPA UNSOED, Purwokerto.

3)Carey, F.A., Sunberg, R.J., 1991. “Advanced Organic Chemistry”, $3^{\text {rd }}$ ed., Part B : Reaction and Synthesis, Plenum Press, New York.

4)Darmawan, A ., 2008. "Sintesis dan uji bioaktivitas senyawa analog UK-3A Pikolinil serin oktil ester dan pikolinil serin oktil oktanoil ester, Tesis, Magister Sains Ilmu Kimia, Program Pascasarjana U.I, Depok.

5)Firmansyah, F., 2003. “Optimasi Sintesis Senyawa 2-Hidroksi-N-Fenil Benzamida”. Skripsi, Fakultas Farmasi, Universitas Pancasila, Jakarta.

6)Griffer, R.J., Bobbitt, J.M., Schwarting, A.E., 1991. “Pengantar Kromatografi”, Edisi kedua, ITB Press, Bandung.

7)Hanafi, M., 1995. “Studies of Novel Antibiotics Metabolites from Streptomyces sp. 51702", Thesis, Departement of Chemistry Faculty of Science, Osaka City University, Osaka.

8)Hanafi, M., Shibata, K., Ueki, M., Taniguchi, M. 1996., “UK-2A, B, C, and D: a Novel Antifungal Antibiotics from Streptomyces sp. 517-02 : II. Structural Elucidation”, J. Antibiotics, 49 (12): 1226-1226.

9)Hanafi, M., Ueki, M., Kusumoto, A., Shibata, K., Tanaka, T., Taniguchi, M., 1997. "UK-3A, a Novel Antifungal from Streptomyces sp. 517-02 : Fermentation, Isolation, Structural Elucidation, and Biological Properties”, J. Antibiotics, 50 (7): 551-555.

10) Hanafi, M., Trisnamurti, R.H., Saefudin, E., Thelma, A.B., Ngadiman., 1997a. "Sintesis dan uji aktivitas biologi senyawa analog UK-3, 3-hidroksipikolinil serin metil ester dan turunannya", Prosiding Seminar Nasional Kimia II; Yogyakarta 13 Desember 1997, Jurusan Kimia Fakultas MIPA UGM. ISSN: 1410-8313, Yogyakarta.

11) Hanafi, M., Trisnamurti, R.H., Thelma, A.B., Herlina., 1997b. “Optimasi pembentukan senyawa analog antibiotik UK-3, 3-hidroksipikolinil serin metil ester", Prosiding Seminar Nasional 24-27 November 1997, Himpunan Kimia Indonesia Bandung Cabang Jawa Barat, p. 69-74. 
12) Hanafi, M., Thelma A.B., 1998. "Sintesis Senyawa Analog Antibiotika UK-3, Pengaruh Gugus Hidroksi terhadap Aktivitas Biologi”, Prosiding Seminar Nasional II Kimia dalam Pembangunan Holiday Inn., Yogyakarta.

13) Hanafi, M., 1998. “Sintesis Senyawa Analog dengan Antibiotik UK-3”. Laporan Riset Unggulan Terpadu V 1997/1998”, Kantor Menteri Negara Riset dan Teknologi Dewan Riset Nasional.

14) Hanafi, M., Anita,Y., Putra, A.M.J., 2008. "SintesisPengaruh Lipofilisitas Pada Analog UK-3A terhadap Aktivitas Antikanker Leukemia P-388”, Seminar IPT, LIPI, Serpong.

15) Harbone, J.B., Dey, P.M., 1991. “Method in Plant Biochemistry”, 6, Assay for Bioactivity, Academic Press, London.

16) Hendayana, S., Karohman, A., Sumarna, A.A., Supriatna, A., Buchari, 1994. “Kimia Analitik Instrumen”, IKIP, Semarang Press, Semarang.

17) Husniati,. 2008. "Sintesis Senyawa Analog Uk-3A : 3-Hidroksi-N-oktilpikolinamida, 2-Hidroksi- $N$-fenilbenzamida, 3-Hidroksi- $N$-fenilpikolinamida, dan 2-Hidroksi- $N$ oktilbenzamida, dan Uji Bioaktivitas Secara In Vitro terhadap Sel Kanker Murine Leukemia P-388”, Tesis, Magister Sains Ilmu Kimia, Program Pascasarjana U.I, Depok.

18) Kurnia, A., 2007. "Sintesis dan Uji Aktivitas Biologi Senyawa Analog Antibiotika UK3 : Diamilnikotinil Glutamat Ester dan Diheksil nikotinil Glutamat Ester”, Tesis, Magister Sains Ilmu Kimia, Program Pascasarjana U.I, Depok.

19) March, J., 1992. "Advenced Organic Chemistry, reaction, mechanism and structure”, $4^{\text {th }}$ ed., A Wiley Interscience, New York.

20) Martin, G.S., 1999. “Normal cell and cancer cells: In Bioshop”, Weinberg, R.A., Ed., Molecular oncology, Scientific American, New York, p.13-40.

21) Murray, R.K., Dearyl, K. G., Mayes, P.A., Rodwell, V.W., 2003. “Biokimia”, Andry Hartono, Ed., Edisi ke-25, EGC, Jakarta.

22) Patrick, G., 2001. “Instant notes in medicinal chemistry”, BIOS Scientific Publisher.

23) Pine, S.H., Hendrickson, J.B., Crom, D.C., 1998. “Kimia Orgnik 2”, Peterjemah: Roehyati, J., Susanti, W.B., Penerbit ITB, Bandung.

24) Rahmawati, N., 2004. “Uji Sitotoksisitas Ekstrak Etanolik Daun Bandotan (Ageratum conyzoides L) terhadap Sel HeLa dan Profil Kromatografi Lapis Tipisnya”, Skripsi, Fakultas Farmasi, Universitas Gadjah Mada, Yogyakarta. 
25) Rosalina, L., 1999. "Sintesis dan Uji Aktivitas Biologi Senyawa Analog Antibiotika UK-3A : 3-Hidroksipikolinil Dialkil Glutamat Ester dan 2-hidroksinikotinil Dialkil Glutamat Ester", Tesis, Magister Sains Ilmu Kimia, Program Pascasarjana UI, Depok.

26) Sastrohamidjoyo, H., 1992. “Spektroskopi Infra Merah”. UGM, Yogyakarta.

27) Shiomi, K., Hatae, K., Hatano, H., Matsumono, A., Takahashi, Y., Lin Jiang, C., Tomoda, H., Kobayashi, S., Tanaka, H., Omura, S., 2005. “A New Antibiotic, Antimycin A9, Produced by Streptomyces sp. K01-0031 ”, J.Antibiotic, 58(1): 74-78.

28) Shimano, M., Kamei, N., Shibata, T., Inoguchi, K., Itoh, N., Ikari, T., Senda, H., 1998. "Total Synthesis of the Antifungal Dilactones UK-2A and UK3A : The Determination of their Relative and Absolute Configurations". Tetrahedron Lett., 39 : 4363-4366.

29) Siswandono, B., Soekardjo, 2000. “Kimia Medisinal”, Jilid 1, Airlangga, University Press., Surabaya.

30) Shi, Y., Cidlowski, J., Scott, D., Wu, J., Shi, Y.B., 2003. “Molecular Mechanisms of Programmed Cell Death”. Kluwer Academic/Plenum, New York

31) Taniguchi, M., Shibata, K., Abe. K., Kodama, R., Uotani, K., 1995. Jpn. Pattent, 7 233165.

32) Taniguchi, M., 2005. "Semisynthesis and Biological Evaluation of Analogues of UK3A, a Novel Antifungal Antibiotics from Streptomyces sp. 517-02”, Bioorg. Med. Chem. Lett. 15: 2011-2014. 